\title{
Opłata za prawo do dysponowania częstotliwością - glosa do wyroku Naczelnego Sądu Administracyjnego z dnia 27 listopada 2018 r., II GSK 3446/16
}

\author{
Fee for the right to use a radio frequency. Gloss on the Judgement of the Supreme \\ Administrative Court of 27 November 2018, II GSK 3446/16 \\ Плата за право использования радиочастот. Комментарий к постановлению \\ Высшего административного суда от 27 ноября 2018 г., II GSK 3446/16
}

\author{
ANDRZEJ KRASUSKI \\ Dr hab., Uniwersytet Humanistyczno-Przyrodniczy im. Jana Długosza w Częstochowie \\ e-mail: akrasuski@akrasuski.com, https://orcid.org/0000-0002-7724-3751
}

\begin{abstract}
Streszczenie: Glosowany wyrok NSA z dnia 27 listopada 2018 r., II GSK 3446/16, dotyczy ustalenia podstaw prawnych poddania się istotnemu obowiązkowi uiszczania rocznych opłat za prawo do dysponowania częstotliwością. W wyroku tym Naczelny Sąd Administracyjny dokonał wykładni przepisu art. 185 ust. 1 ustawy Prawo telekomunikacyjne w zw. z art. 114 ust. 1 oraz art. 123 ust. 1 pkt 1 i 3 tej ustawy w kontekście ustalenia powstania obowiązku zapłaty opłaty za prawo do dysponowania częstotliwością. Duża skala działalności telekomunikacyjnej prowadzona z wykorzystaniem częstotliwości, jak również brak definicji legalnych terminów "dysponowanie częstotliwością” oraz „prawo do dysponowania częstotliwością” czynią to zagadnienie istotnym z punktu widzenia bezpieczeństwa obrotu prawnego.
\end{abstract}

Słowa kluczowe: przedsiębiorca telekomunikacyjny, częstotliwości, Prezes Urzędu Komunikacji Elektronicznej, nadpłata, dysponowanie częstotliwością, pozwolenie radiowe, rezerwacja częstotliwości, urządzenie radiowe

\begin{abstract}
Summary: The judgement of the Supreme Administrative Court of 27 August 2018, II GSK 3446/16, subject of this gloss concerns the determination of an important obligation to pay an annual fee for the right to use a radio frequency. In this judgement, the Supreme Administrative Court set out the interpretation of Article 185 par. 1 of the TL in connection with Article 114 par. 1 and Article 123 par. 1 subpar. 1 and 3 of the TL in the context of determining the establishment of the obligation to make payments of the fee for using a radio frequency. The large scale of telecommunications activity conducted with the use of radio frequencies as well as lack of legal definitions of the terms: "use of a radio frequency" and "the right to use a radio frequency" make this an important issue from the perspective of legal security.
\end{abstract}

Key words: telecommunications entrepreneur, frequencies, President of the Electronic Communication Office, payment in excess, use of a frequency, radio permit, reservation of frequencies, radio equipment

Резюме: Комментируемое решение Высшего административного суда от 27 ноября 2018 г., II GSK 3446/16, касается определения юридических оснований для предъявления материального обязательства по уплате ежегодной платы за право использования радиочастотного ресурса. В этом решении Высший административный суд истолковал ст. 185 п. 1 польского «Закона о телекоммуникации» в связи с ст.114 п. 1 и ст. 123 абзац. 1, п. 1 и 3 этого закона в контексте установления обязательств по перечислении платы за право использования радиочастотного ресурса. Большой масштаб телекоммуникационной деятельности, осуществляемой с использованием радиочастот, а также отсутствие законодательных определений терминов «использование радиочастот» и «право на использование радиочастот» делают этот вопрос важным с точки зрения безопасности юридического оборота.

Ключевые слова: телекоммуникационный предприниматель, радиочастоты, Президент Управления электронных коммуникаций, переплата, использование радиочастот, радиолицензия, резервирование радиочастот, радиоустройство 
1. Zgodnie z art. 185 ust. 1 ustawy Prawo telekomunikacyjne podmiot, który uzyskat prawo do dysponowania częstotliwościa w rezerwacji częstotliwości, uiszcza roczne opłaty za prawo do dysponowania częstotliwościa. Już sama wykładnia językowa prowadzi do wniosku, że opłata, o której mowa w tym przepisie jest ściśle zwiazana $z$ uzyskaniem "prawa do dysponowania częstotliwościa w rezerwacji częstotliwości”, a nie $z$ samym dokonaniem przez organ rezerwacji, jak $w$ przypadku jednorazowej oplaty przewidzianej w art. 185 ust. 4 ustawy - Prawo telekomunikacyjne.

2. Wykładnia zmierzajaca do przyjęcia, że opłata ustanowiona $w$ tym przepisie jest należna również za okres, w którym podmiot, na rzecz którego dokonano rezerwacji, nie miał prawa do korzystania z częstotliwości objętych rezerwacją, w szczególności nie mógł żądać udzielenia mu pozwoleń radiowych, a w konsekwencji nie mógł prowadzić swojej działalności z wykorzystaniem tych częstotliwości, jest sprzeczna $z$ art. $13 d y$ rektywy 2002/20/WE Parlamentu Europejskiego i Rady z dnia 7 marca 2002 r.

\section{Wstęp}

Wyrok NSA z dnia 27 listopada 2018 r., II GSK 3446/16', zapadł w następujących okolicznościach sprawy.

Decyzją $\mathrm{nr}[\ldots]$ z [...] grudnia 2003 r. ówczesny Prezes Urzędu Regulacji Telekomunikacji i Poczty (dalej: Prezes URTiP) dokonał rezerwacji na rzecz O. Sp. z o.o., tj. poprzednika prawnego S. S.A. ${ }^{2}$, czterech dupleksowych kanałów częstotliwościowych o szerokości $1,25 \mathrm{MHz}$, w zakresie $838-843 \mathrm{MHz}$ oraz $883-888 \mathrm{MHz}$, przeznaczonych do wykorzystywania dla radiowego dostępu abonenckiego w stacjonarnej publicznej sieci telefonicznej na obszarze Polski, do dnia 31 grudnia $2018 \mathrm{r}$.

Powyższa decyzja rezerwacyjna była wielokrotnie zmieniana decyzjami Prezesa URTiP, a następnie Prezesa Urzędu Komunikacji Elektronicznej (dalej: Prezes UKE lub Organ). W ramach tych zmian decyzją z [...] grudnia $2013 \mathrm{r}$. nr [...] (dalej: decyzja z grudnia 2013 r.) Prezes UKE, działając z urzędu, odebrał S. S.A. dotychczasowe częstotliwości i przyznał częstotliwości obejmujące blok o szerokości $2 \times 5 \mathrm{MHz}$ z zakresu $816-821 \mathrm{MHz}$ oraz $857-862 \mathrm{MHz}$ (dalej: Nowe Pasmo), na obszarze całego kraju. W pkt I.3 decyzji z grudnia 2013 r. wskazane zostało, że S. S.A. jest uprawniona do rozpoczęcia wykorzystywania częstotliwości od dnia

1 Wyrok NSA z dnia 27 listopada 2018 r., II GSK 3446/16, LEX nr 2619053.

2 Z dniem 22 grudnia 2005 r. O. Sp. z o.o. przekształciła się w S. S.A., która jest następcą prawnym O. Sp. z o.o. 
wydania przez Prezesa UKE decyzji w sprawie rezerwacji częstotliwości dla podmiotów wyłonionych w aukcji na rezerwację częstotliwości z zakresu $791-816 \mathrm{MHz}$ i $832-857 \mathrm{MHz}$ oraz z zakresu $2500-2570 \mathrm{MHz}$ i $2620-2690 \mathrm{MHz}$ na obszarze całego kraju, przeznaczonych do świadczenia usług telekomunikacyjnych w służbie ruchomej lub stałej, ale nie później niż od dnia 1 października 2014 r. Decyzji tej został nadany rygor natychmiastowej wykonalności.

Następnie decyzją z [...] września 2014 r. nr [...] (dalej: decyzja z września 2014 r.) Prezes UKE uchylił decyzję z grudnia 2013 r. w części i ustalił w tej decyzji nową treść pkt I.3, stwierdzając, że S. S.A. jest uprawniona do rozpoczęcia wykorzystywania zarezerwowanych częstotliwości od dnia wydania przez Prezesa UKE decyzji w sprawie rezerwacji częstotliwości dla podmiotów wyłonionych w aukcji na rezerwację częstotliwości z zakresu $791-816 \mathrm{MHz}$ i $832-857 \mathrm{MHz}$ oraz z zakresu 2500-2570 i 2620-2690 MHz na obszarze całego kraju, przeznaczonych do świadczenia usług telekomunikacyjnych w służbie ruchomej lub stałej, ale nie później niż od dnia 1 stycznia $2015 \mathrm{r}$.

W dniu 20 listopada 2014 r. Prezes UKE wystawił upomnienie nr [...], w którym wezwał S. S.A. do zapłaty opłaty za cztery kwartały 2014 r. za prawo do dysponowania częstotliwościami na podstawie decyzji z grudnia 2013 r., wraz z odsetkami. W dniu 1 grudnia 2014 r. S. S.A. wpłaciła na rachunek Urzędu Komunikacji Elektronicznej kwotę 3130 368,60 zł. Pismem z dnia 14 stycznia 2015 r. S. S.A. zwróciła się do Prezesa UKE o stwierdzenie nadpłaty i jej zwrot w kwocie 3130 368,60 zł z tytułu „opłaty za prawo do dysponowania częstotliwością wraz z odsetkami i kosztami upomnienia”. We wniosku tym spółka zażądała również zapłaty odsetek od dnia 1 grudnia $2014 \mathrm{r}$.

Decyzją z [...] marca 2015 r. nr [...] (dalej: decyzja pierwszej instancji) Prezes UKE odmówił stwierdzenia nadpłaty z tytułu opłat za poszczególne kwartały 2014 r. oraz z tytułu kosztów upomnienia. W decyzji ostatecznej z [...] czerwca 2015 r. (dalej: decyzja ostateczna) Prezes UKE utrzymał w mocy decyzję pierwszej instancji. Wyrokiem z dnia 10 marca 2016 r., VI SA/Wa 2015/15³ (dalej: wyrok z 2016 r.), WSA w Warszawie (dalej: sąd pierwszej instancji) oddalił skargę S. S.A. na decyzję ostateczną.

Istota niniejszej sprawy sprowadza się do ustalenia, czy Prezes UKE był uprawniony do żądania od S. S.A. zapłaty rocznej opłaty za prawo do dysponowania częstotliwością, w trybie art. 185 ust. 1 ustawy Prawo telekomunikacyjne ${ }^{4}$, za 2014 r., w związku z wydaniem decyzji z grudnia 2013 r., której z urzędu nadany został

3 Wyrok WSA w Warszawie z dnia 10 marca 2016 r., VI SA/Wa 2016/15, LEX nr 2055308.

4 Ustawa z dnia 16 lipca 2004 r. - Prawo telekomunikacyjne, tekst jednolity: Dz. U. z 2021 r. poz. 576. 
rygor natychmiastowej wykonalności, zmienionej w części decyzją z września 2014 r. Zgodnie z art. 185 ust. 1 ustawy Prawo telekomunikacyjne podmiot, który uzyskał prawo do dysponowania częstotliwością w rezerwacji częstotliwości, uiszcza roczne opłaty za prawo do dysponowania częstotliwością.

W szerszym ujęciu glosowany wyrok NSA odnosi się do analizy użytego w art. 185 ust. 1 ustawy Prawo telekomunikacyjne terminu „prawo do dysponowania częstotliwością" $w$ dwóch aspektach, tj. z punktu widzenia S. S.A. jako podmiotu uprawnionego $\mathrm{z}$ decyzji rezerwacyjnej oraz obowiązku uiszczenia rocznej opłaty z tytułu prawa do dysponowania częstotliwością.

\section{Prawo do dysponowania częstotliwością}

Częstotliwość radiowa stanowi zasób do przekazywania sygnałów w sieci telekomunikacyjnej ${ }^{5}$. Zgodnie z art. 2 pkt 35 ustawy Prawo telekomunikacyjne sieć telekomunikacyjna obejmuje systemy transmisyjne oraz urządzenia komutacyjne lub przekierowujące, a także inne zasoby, w tym nieaktywne elementy sieci, które umożliwiają nadawanie, odbiór lub transmisję sygnałów za pomocą środków wykorzystujących energię elektromagnetyczną. Wśród środków tych ustawodawca wymienia fale radiowe, obok przewodów, środków optycznych (włókno światłowodowe). Świadczenie usług telekomunikacyjnych, polegających (głównie) na przekazywaniu sygnałów w sieci telekomunikacyjnej (zob. art. 2 pkt 48) jest celem, dla którego Prezes UKE przydziela częstotliwości na czas określony w formie decyzji administracyjnej, zwanej na podstawie art. 114 ust. 1 ustawy Prawo telekomunikacyjne decyzją w sprawie rezerwacji częstotliwości. Zgodnie z tym przepisem rezerwacja częstotliwości lub zasobów orbitalnych, zwana dalej rezerwacją częstotliwości, określa częstotliwości lub zasoby orbitalne, które w okresie rezerwacji pozostają w dyspozycji podmiotu, na rzecz którego dokonano rezerwacji, przeniesiono uprawnienia do częstotliwości lub uprawnienia do dysponowania częstotliwościami na cele związane z uzyskiwaniem pozwoleń radiowych.

Aby częstotliwości mogły zostać użyte do przekazywania sygnałów, w ramach świadczonych usług telekomunikacyjnych, w polskim systemie prawnym

5 Częstotliwości stanowią istotny zasób do prowadzenia działalności telekomunikacyjnej, umożliwiając komercyjne zastosowanie naziemnej oraz satelitarnej łączności radiowej, zob. Raport o stanie rynku telekomunikacyjnego w Polsce w 2018 r., Urząd Komunikacji Elektronicznej, https://www .uke.gov.pl/akt/raport-o-stanie-rynku-telekomunikacyjnego-w-polsce-w-2018-r-,223.html [dostęp: 14.04.2020 r.]. 
przewidziano następujące prawne formy reglamentacji działalności telekomunikacyjnej. Po pierwsze, podmiot zainteresowany świadczeniem usług telekomunikacyjnych z wykorzystaniem częstotliwości występuje z wnioskiem do Prezesa UKE o ich przydział na czas oznaczony. Przydział ten odbywa się w formie decyzji w sprawie rezerwacji częstotliwości, jaką Prezes UKE wydaje na podstawie art. 114 ust. 1 oraz 115 ustawy Prawo telekomunikacyjne. Ten drugi przepis określa treść decyzji w sprawie rezerwacji częstotliwości, w tym m.in. zakres częstotliwości lub pozycje orbitalne objęte rezerwacją (art. 115 ust. 1 pkt 2), termin, w jakim podmiot jest uprawniony do wykorzystywania częstotliwości (art. 115 ust. 1 pkt 5) oraz warunki do wydania pozwolenia radiowego uwzględniające warunki wynikające z umów międzynarodowych, których Polska jest stroną (art. 115 ust. 1 pkt 6). Po drugie, wykorzystywane do świadczenia usług telekomunikacyjnych sieci telekomunikacyjne, oparte na widmie radiowym, umożliwiają komunikację pomiędzy określonymi urządzeniami radiowymi. Zgodnie z definicją równościową ${ }^{6}$, zawartą w art. 2 pkt 45 ustawy Prawo telekomunikacyjne, urządzeniem radiowym jest urządzenie telekomunikacyjne, które celowo emituje lub odbiera fale radiowe na potrzeby radiokomunikacji lub radiolokacji albo urządzenie telekomunikacyjne, które musi zostać uzupełnione o dodatkowy element, aby mogło celowo emitować lub odbierać fale radiowe na potrzeby radiokomunikacji lub radiolokacji. Używanie urządzeń radiowych jest przedmiotem reglamentacji wyrażającej się w obowiązku uprzedniego uzyskania pozwolenia radiowego, zgodnie z art. 143 ust. 1 ustawy Prawo telekomunikacyjne ${ }^{7}$.

Ustawodawca zobowiązał podmiot, na rzecz którego wydana została rezerwacja częstotliwości, do jak najszybszego uzyskania pozwoleń radiowych, na podstawie których podmiot ten będzie mógł świadczyć usługę telekomunikacyjną w sieci telekomunikacyjnej, opartej na przyznanej częstotliwości. W tym celu ustawodawca przewidział gwarancje dla podmiotu, który uzyskał rezerwację częstotliwości. Po pierwsze, na podstawie przepisu art. 143 ust. 4 ustawy Prawo telekomunikacyjne podmiot, na rzecz którego wydana została decyzja w sprawie rezerwacji częstotliwości, upoważniony został - z mocy ustawy Prawo telekomunikacyjne - do żądania od Prezesa UKE wydania pozwolenia radiowego w zakresie przydzielonego zasobu częstotliwości w okresie obowiązywania rezerwacji częstotliwości. Po drugie, w przypadku gdy na podstawie art. $122^{1}$ ust. 1 ustawy Prawo telekomunikacyjne

6 M. Zieliński, Wykładnia prawa. Zasady. Reguły. Wskazówki, Warszawa 2002, s. 189.

$7 \mathrm{Na}$ temat wyłączenia $\mathrm{z}$ zakresu obowiązku uzyskania pozwolenia radiowego zob. art. 144 ustawy Prawo telekomunikacyjne oraz rozporządzenie Ministra Administracji i Cyfryzacji z dnia 12 grudnia 2014 r. w sprawie urządzeń radiowych nadawczych lub nadawczo-odbiorczych, które mogą być używane bez pozwolenia radiowego, tekst jednolity: Dz. U. z 2017 r. poz. 96. 
podmiot, na rzecz którego dokonano rezerwacji częstotliwości, wydzierżawi te częstotliwości, wówczas dzierżawcy przysługuje na podstawie art. 143 ust. 4 tej ustawy również prawo do żądania od Prezesa UKE wydania pozwolenia radiowego. Po trzecie, postępowanie w sprawie wydania pozwolenia radiowego jest postępowaniem odformalizowanym $\mathrm{w}$ stosunku do postępowania $\mathrm{w}$ sprawie rezerwacji częstotliwości. Zgodnie $\mathrm{z}$ art. 115 ust. 1 pkt 5 ustawy Prawo telekomunikacyjne w decyzji rezerwacyjnej ten sam organ prowadzący obydwa postępowania określa warunki wydania pozwolenia radiowego. Ustawodawca wyznaczył ponadto terminy załatwienia sprawy. Jak wskazuje się w literaturze przedmiotu, „rola terminów jest dwojaka. Z jednej strony (technicznej) termin ma przyczynić się do uporządkowania trybu postępowania administracyjnego, do niedopuszczenia do jego przewlekłości. Z drugiej zaś ustalone w Kodeksie postępowania administracyjnego ${ }^{8}$ terminy chronią obywatela przed ewentualną samowolą pracownika administracyjnego i umożliwiają obywatelowi zorganizowanie należytej ochrony przysługujących mu uprawnień"

Prezes UKE zobowiązany jest wydać pozwolenie radiowe zgodnie $\mathrm{z}$ art. 12 K.p.a. w zw. z art. 206 ust. 1 ustawy Prawo telekomunikacyjne. Na podstawie art. 143 ust. 6 tej regulacji pozwolenie radiowe powinno być wydane w terminie 6 tygodni, licząc od dnia złożenia wniosku. Natomiast w przypadku wystąpienia sytuacji określonej w art. 143 ust. 7 ustawy Prawo telekomunikacyjne należy stosować przepisy K.p.a. regulujące terminy załatwiania spraw, w tym art. 35 K.p.a. ${ }^{10}$ Przepis art. 143 ust. 6 i 7 ustawy Prawo telekomunikacyjne implementuje art. 5 ust. 3 Dyrektywy Parlamentu Europejskiego i Rady 2002/20/WE z dnia 7 marca 2002 r. ${ }^{11}$

Z punktu widzenia systematyki ustawy Prawo telekomunikacyjne zobowiązanie podmiotu, na rzecz którego wydana została decyzja w sprawie rezerwacji częstotliwości, do niezwłocznego złożenia wniosku w sprawie wydania pozwolenia radiowego znajduje odzwierciedlenie w zobowiązaniu do efektywnego wykorzystania częstotliwości. Zgodnie z art. 123 ust. 1 pkt 8 tej ustawy w przypadku, gdy częstotliwości objęte rezerwacją wykorzystywane są w sposób nieefektywny, Prezes UKE może z urzędu cofnąć rezerwację częstotliwości bądź dokonać jej zmiany. Uzasadnienie obowiązku efektywnego wykorzystania częstotliwości wynika z charakteru

8 Ustawa z dnia 14 czerwca 1960 - Kodeks postępowania administracyjnego, tekst jednolity: Dz. U. z 2020 r. poz. 256 z późn. zm. (dalej: K.p.a.).

9 J. Starościak, Prawo administracyjne, Warszawa 1977, s. 279.

10 Wyrok NSA z dnia 8 lutego 2017 r., II GSK 5196/16, LEX nr 2226468.

11 Dyrektywa Parlamentu Europejskiego i Rady 2002/20/WE z dnia 7 marca 2002 r. w sprawie zezwoleń na udostępnienie sieci i usług łączności elektronicznej (dyrektywa o zezwoleniach), Dz. Urz. UE L 108 z 24.04.2002, s. 21 z późn. zm. (akt uchylony, dalej: Dyrektywa). 
prawnego częstotliwości jako dóbr ograniczonych, których przydział poprzedza zwykle postępowanie selekcyjne w postaci przetargu, konkursu albo aukcji.

Obowiązek efektywnego wykorzystania częstotliwości jako dóbr rzadkich znajduje uzasadnienie w celach ustawy Prawo telekomunikacyjne ${ }^{12}$, w tym w celu dotyczącym stworzenia warunków dla rozwoju i wykorzystania nowoczesnej infrastruktury telekomunikacyjnej. Drugim mającym zastosowanie do tej argumentacji celem ustawy Prawo telekomunikacyjne jest stworzenie warunków dla zapewnienia użytkownikom maksymalnych korzyści w zakresie różnorodności, ceny i jakości usług telekomunikacyjnych (zob. art. 1 ust. 2 pkt 4 tej ustawy).

\section{Roczna opłata za prawo do dysponowania częstotliwością}

Chcąc ustalić, czy w związku z wydaniem decyzji z grudnia 2013 r., uchylonej w części na podstawie decyzji z września 2014 r., S. S.A. była zobowiązana do uiszczenia opłaty, o której mowa w art. 185 ust. 1 ustawy Prawo telekomunikacyjne, za okres od 31 grudnia 2013 r. do 31 grudnia 2014 r., wymagane jest uprzednie zbadanie, czy S. S.A. w tym okresie przyznane zostało prawo „do dysponowania częstotliwością w rezerwacji częstotliwości”.

W literaturze przedmiotu przyjmuje się, że „rekonstruowanie znaczenia przepisów prawa budzących wątpliwości przy pomocy wykładni językowej nie zawsze przynosi pożądane efekty. Szczególnie w prawie administracyjnym dekodowanie znaczenia normy prawnej za pomocą wykładni gramatycznej może przynieść niedostateczny efekt"13. W ocenie Sądu Najwyższego priorytet wykładni gramatycznej „mógłby być aprobowany tylko w warunkach dużej spójności systemu prawa i dyscypliny legislacyjnej samego ustawodawcy"14. W procesie stosowania normy organ musi ustalić jej znaczenie poprzez określenie kategorii stosunków społecznych, które swoim zakresem wyczerpują hipotezę normy. Egzegeza przepisu prawa wymaga też ustalenia obowiązywania danej normy w miejscu i czasie ${ }^{15}$. Dokonując wykładni, organ musi ustalić znaczenie wszystkich słów użytych w przepisach,

12 Zob. art. 1 ust. 2 pkt 2 ustawy Prawo telekomunikacyjne.

13 W. Jakimowicz, Wykładnia w prawie administracyjnym, Zakamycze 2006, s. 428-429; B. Brzeziński, Szkice z wykładni prawa podatkowego, Gdańsk 2002, s. 19-34.

14 Wyrok SN z dnia 8 stycznia 1993 r., III ARN 84/92, OSNC 1993, nr 10, poz. 183.

15 M. Wincenciak, Sankcje w prawie administracyjnym i procedura ich wymierzania, Warszawa 2008, s. 37. 
a różnica w swobodzie interpretacji pomiędzy określeniami ostrymi a nieostrymi ma charakter jedynie ilościowy, nie zaś jakościowy ${ }^{16}$.

$\mathrm{Z}$ literalnego brzmienia art. 185 ust. 1 ustawy Prawo telekomunikacyjne wynika, że podmiotem zobowiązanym do uiszczenia rocznej opłaty jest tylko taki podmiot, wobec którego można stwierdzić, że przysługuje mu prawo do dysponowania częstotliwością. Ustawodawca poprzez użycie przyimka „w” („[... podmiot, który uzyskał prawo do dysponowania częstotliwością w rezerwacji częstotliwości”) wyraźnie wskazuje, że źródłem tego uprawnienia może być tylko treść decyzji w sprawie rezerwacji częstotliwości, o której mowa w art. 115 ust. 1 ustawy Prawo telekomunikacyjne.

W ramach wykładni językowej analizie poddać należy zwrot „prawo do dysponowania częstotliwością”. Podstawowe znaczenie słowa dysponować to „mieć coś do dyspozycji”" ${ }^{17}$, „mieć możliwość użycia czegos” ${ }^{18}$. Dysponowanie częstotliwością polega na żądaniu wydania pozwoleń radiowych. Bez możliwości pozyskiwania pozwoleń radiowych uprawnienie z rezerwacji jest uprawnieniem „iluzorycznym”, zaś podmiot wskazany w decyzji "nie ma rezerwacji do dyspozycji” ${ }^{19}$.

Wykładnia celowościowa (funkcjonalna) zmierza do uwzględnienia takiego rozumienia przepisów, aby w sposób możliwie pełny prawo realizowało cele ustawodawcy $^{20}$. Nakazuje jego interpretację w powiązaniu $\mathrm{z}$ innymi przepisami ustawy Prawo telekomunikacyjne. W ustawie tej określone zostały konsekwencje prawne związane z niezrealizowaniem uprawnienia do żądania wydania pozwolenia radiowego przez dysponenta rezerwacji częstotliwości.

Zgodnie z art. 114 ust. 1 ustawy Prawo telekomunikacyjne rezerwacja częstotliwości określa częstotliwości lub zasoby orbitalne, które w okresie rezerwacji pozostają w dyspozycji podmiotu, na rzecz którego dokonano rezerwacji, przeniesiono uprawnienia do częstotliwości lub uprawnienia do dysponowania częstotliwościami na cele związane z uzyskiwaniem pozwoleń radiowych. Z kolei elementy składowe decyzji w sprawie rezerwacji częstotliwości zostały określone w art. 115 ust. 1 ustawy Prawo telekomunikacyjne. W przepisie tym ustawodawca zawarł elementy obligatoryjne decyzji w sprawie rezerwacji częstotliwości oraz elementy fakultatywne. Zgodnie z art. 115 ust. 1 pkt 5 tej ustawy elementem obligatoryjnym każdej decyzji $\mathrm{w}$ sprawie rezerwacji częstotliwości jest termin, w jakim podmiot jest uprawniony

16 A. Nałęcz, w: Kryzys prawa administracyjnego? t. 1. Jakość prawa administracyjnego, red. D.R. Kijowski, A. Miruć, P.J. Suwaj, 2012 [wyd. el. LEX].

17 Stownik języka polskiego, https://sjp.pwn.pl/sjp/dysponowac;2555797.html [dostęp: 21.04.2020 r.].

18 https://pl.wiktionary.org/wiki/dysponowa\%C4\%87 [dostęp: 20.04 .2020 r.].

19 Stownik języka polskiego, t. 1, red. S. Dubisz, Warszawa 2003, s. 750.

20 W. Jakimowicz, Wykładnia w prawie..., s. 429. 
do rozpoczęcia wykorzystywania częstotliwości. W ustawie Prawo telekomunikacyjne wykorzystanie częstotliwości w obrocie gospodarczym następuje poprzez uzyskanie uprawnienia do używania urządzeń radiowych, pracujących w określonych pasmach częstotliwości. Wykorzystanie urządzeń radiowych następuje na podstawie decyzji administracyjnej Prezesa UKE, zwanej pozwoleniem radiowym.

Zgodnie $\mathrm{z}$ art. 143 ust. 4 ustawy Prawo telekomunikacyjne podmiot, który posiada rezerwację częstotliwości, może żądać wydania pozwolenia radiowego dotyczącego wykorzystania zasobu częstotliwości objętego rezerwacją częstotliwości w okresie jej obowiązywania. Postępowanie w sprawie wydania pozwolenia radiowego jest postępowaniem nieskomplikowanym, w odniesieniu do którego ustawodawca określił terminy załatwienia sprawy, o czym świadczy sformułowanie przepisu art. 143 ust. 4 przywołanej ustawy o prawie żądania wydania pozwolenia radiowego. Termin „dysponowanie rezerwacją częstotliwości” oznacza zatem realizację uprawnienia dysponenta rezerwacji częstotliwości do żądania wydania pozwolenia radiowego, aby dysponent ten mógł z rezerwacji częstotliwości skorzystać. Uprawnienie do żądania wydania pozwolenia radiowego należy zatem analizować w połączeniu z przepisem art. 115 ust. 1 pkt 5 ustawy Prawo telekomunikacyjne. W konsekwencji „prawo do dysponowania częstotliwością”, o którym mowa w art. 185 ust. 1 ustawy Prawo telekomunikacyjne, oznacza uprawnienie do żądania wydania pozwoleń radiowych pracujących w zakresie częstotliwości określonych w decyzji rezerwacyjnej.

Powyższy sposób rozumienia terminu „prawo do dysponowania częstotliwością" jest zgodny z wykładnią celowościową przepisu art. 185 ust. 1 ustawy Prawo telekomunikacyjne. Wykładnia celowościowa tego przepisu nakazuje jego interpretację w powiązaniu z innymi przepisami rzeczonej ustawy. W regulacji tej określone zostały konsekwencje prawne związane $\mathrm{z}$ niezrealizowaniem uprawnienia do żądania wydania pozwolenia radiowego przez podmiot uprawniony z rezerwacji.

W art. 123 ust. 1 pkt 8 ustawy Prawo telekomunikacyjne ustawodawca przewidział konsekwencje nieefektywnego wykorzystania częstotliwości przez dysponenta rezerwacji częstotliwości, wskazując, że rezerwacja częstotliwości może zostać zmieniona lub cofnięta $\mathrm{w}$ drodze decyzji Prezesa UKE w przypadku, gdy częstotliwości objęte rezerwacją są wykorzystywane w sposób nieefektywny. Wykorzystanie częstotliwości w sposób nieefektywny wyraża się również w braku wykorzystania częstotliwości w obrocie gospodarczym w ogóle, poprzez nieskorzystanie z żądania wydania pozwoleń radiowych zgodnie z przepisem art. 143 ust. 4 ustawy Prawo telekomunikacyjne. Innym przykładem jest przewidziane w art. 123 ust. 1 pkt 5 tej ustawy uprawnienie Prezesa UKE do zmiany lub cofnięcia w drodze decyzji administracyjnej rezerwacji częstotliwości, gdy dysponent rezerwacją częstotliwości zaprzestanie 
wykorzystywania częstotliwości przez co najmniej 6 miesięcy, z przyczyn leżących po jego stronie.

Wskazane wyżej konsekwencje prawne, wyrażające się w możliwości zastosowania przez Organ przepisu art. 123 ust. 1 pkt 5 lub 8 ustawy Prawo telekomunikacyjne dowodzą, że prawo do żądania wydania pozwolenia radiowego, składające się na „prawo do dysponowania częstotliwością w rezerwacji częstotliwości”, poczytywać należy jednocześnie jako obowiązek dysponenta rezerwacji częstotliwości do wystąpienia $\mathrm{z}$ wnioskiem o wydanie pozwolenia radiowego. Taki sposób argumentowania uzasadniony jest celami ustawy Prawo telekomunikacyjne. Zgodnie z art. 1 ust. 2 pkt 4 ustawy Prawo telekomunikacyjne jej celem jest zapewnienie użytkownikom maksymalnych korzyści w zakresie różnorodności, ceny i jakości usług telekomunikacyjnych. Z kolei zgodnie z pkt 2 tego ustępu celem ustawy Prawo telekomunikacyjne jest również rozwój i wykorzystanie nowoczesnej infrastruktury telekomunikacyjnej.

Celem przepisu art. 185 ust. 1 ustawy Prawo telekomunikacyjne jest zatem zobowiązanie podmiotu do uiszczenia rocznej opłaty z tytułu rezerwacji częstotliwości, gdy podmiot ten może zrealizować uprawnienie do żądania wydania przez Prezesa UKE pozwolenia radiowego, składające się na prawo do dysponowania częstotliwością. Ustawodawca zamierzał zapewnić, aby podmiot - na rzecz którego wydana została decyzja w sprawie rezerwacji częstotliwości - złożył jak najwięcej wniosków o wydanie pozwoleń radiowych i „uruchomił” określone we wnioskach urządzenia radiowe (od tego zależy efektywność wykorzystania częstotliwości radiowych), pod groźbą zmiany bądź cofnięcia decyzji w sprawie rezerwacji częstotliwości. Funkcja tego przepisu polega również na tym, że podmiot, który miał prawo skorzystać z prawa do dysponowania częstotliwością, a więc uzyskiwać $\mathrm{z}$ tego tytułu przychody, powinien „w zamian” uiścić roczną opłatę.

Wskazana powyżej wykładnia przepisu art. 185 ust. 1 ustawy Prawo telekomunikacyjne - zarówno w ujęciu wykładni językowej, jak i celowościowej - jest zgodna $\mathrm{z}$ wykładnią systemową. W kontekście analizy obligatoryjnego elementu decyzji administracyjnej, tj. powołania podstawy prawnej rozstrzygnięcia ${ }^{21}$, w literaturze przedmiotu wskazano, że „podstawa prawna decyzji administracyjnej musi pozostawać $\mathrm{w}$ pełnej zgodności z jej prawnym charakterem, a więc $\mathrm{z}$ tym, że jest ona indywidualnym aktem administracyjnym. Podstawę takiego aktu stanowią przepisy prawa administracyjnego lub prawa finansowego" ${ }^{22}$. W literaturze przedmiotu podkreśla się, że w odniesieniu do organów administracji publicznej

21 Zob. art. $107 \$ 1$ pkt 4 K.p.a.

22 B. Adamiak, J. Borkowski, Kodeks postępowania administracyjnego. Komentarz, Warszawa 2011, s. 434. 
nie obowiązuje zasada, że mogą one podejmować każde działanie, które nie jest zabronione przez przepisy prawa. Działanie organu administracji zostanie zatem zakwalifikowane jako niezgodne z prawem zarówno wówczas, gdy zostało podjęte niezgodnie $\mathrm{z}$ obowiązującym prawem, jak i wtedy, gdy nie było podstawy prawnej do danego działania ${ }^{23}$.

W doktrynie przyjmuje się, że kwestie związane z pobieraniem dochodów publicznych lub dokonywaniem wydatków publicznych oznaczają wprowadzanie stosownych zmian w zasobach składników majątkowych obywateli i państwa oraz mają wpływ na kształtowanie się zasady ochrony własności, która należy do trwałych elementów współczesnego porządku konstytucyjnego ${ }^{24}$. Zasada ta, jako istotny element państwa prawnego, wywiedziona była przez Trybunał Konstytucyjny z zasady demokratycznego państwa prawnego ${ }^{25}$.

W prawie podatkowym gwarancje konstytucyjnej ochrony wolności praw jednostki i innych podmiotów obrotu gospodarczego są szczególnie potrzebne. Gwarancje te muszą być rozpatrywane nie tylko na płaszczyźnie praworządności formalnej - działania organów państwa zgodnie z nakazem legalności i przestrzegania prawa, ale także w odniesieniu do praworządności materialnej - realizowania wartości obowiązującego systemu prawa ${ }^{26}$.

Przepis art. 217 Konstytucji RP ustanawia bezwzględną wyłączność ustawy dla normowania „nakładania podatków, innych danin publicznych, określania podmiotów, przedmiotów opodatkowania i stawek podatkowych”. W tych materiach konieczne jest więc uregulowanie w samej ustawie wszystkich podstawowych elementów, tak aby unormowanie ustawowe zyskało cechy kompletności, precyzji i jednoznaczności ${ }^{27}$. Kluczowe dla tej sprawy - według Trybunału Konstytucyjnego - jest uwzględnienie zasady ochrony zaufania obywatela do państwa i stanowionego przez nie prawa, mającej swoje źródło w art. 2 Konstytucji RP. Zgodnie z poglądem Trybunału Konstytucyjnego opiera się ona na „pewności prawa, a więc takim zespole cech przysługujących prawu, które zapewniają jednostce bezpieczeństwo prawne; umożliwiają jej decydowanie o swoim postępowaniu w oparciu o pełną znajomość przesłanek działania organów państwowych oraz konsekwencji

23 P. Przybysz, Kodeks postępowania administracyjnego. Komentarz, 2019 [wyd. el. LEX], Komentarz do art. 6, teza 2.

24 C. Kosikowski, Legislacja finansowa, Warszawa 1998, s. 73-76.

25 Zob. art. 217 Konstytucji Rzeczypospolitej Polskiej z dnia 2 kwietnia 1997 r., Dz. U. z 1997 r. Nr 78, poz. 483 z późn. zm.

26 Informacja o istotnych problemach wynikających z działalności i orzecznictwa Trybunału Konstytucyjnego w 1999 roku, Warszawa, marzec 2000 r., https://trybunal.gov.pl/publikacje/informacje -o-problemach-wynikajacych-z-dzialalnosci-i-orzecznictwa-tk/1999 [dostęp: 26.04.2020 r.]. Wyrok TK z dnia 16 czerwca 1998 r., U 9/97, Dz. U. z 1998 r. Nr 75, poz. 506. 
prawnych, jakie ich działania mogą pociągnąć za sobą"28. Rodzi to po stronie państwa obowiązek wprowadzenia takich gwarancji instytucjonalnych, które zapewniłyby organom władzy wykonawczej kontrolę prawidłowego wywiązywania się z tego obowiązku przez wszystkich zobowiązanych ${ }^{29}$. Ustawodawcy dotyczy też wymóg, aby w samej ustawie zostały uregulowane wszystkie podstawowe elementy, i to w sposób kompletny, precyzyjny i jednoznaczny ${ }^{30}$.

Roczną opłatę za prawo do dysponowania częstotliwością, o której mowa w art. 185 ust. 1 ustawy Prawo telekomunikacyjne, zaliczyć należy do kategorii daniny publicznej. Zgodnie bowiem z nauką prawa i orzecznictwem Trybunału Konstytucyjnego za daniny publiczne uważa się świadczenia powszechne, przymusowe, bezzwrotne, ustalane jednostronnie w drodze ustawy i pobierane na rzecz podmiotu prawa publicznego w celu realizacji zadań publicznych ${ }^{31}$. Jest to zatem świadczenie zależne nie od woli osoby, lecz od zakresu podmiotowego i przedmiotowego ustawy podatkowej lub przepisu podatkowego ${ }^{32}$.

W orzecznictwie wskazane zostało, że: „Opłaty za usługi wodne, chociaż nie są tak powszechną daniną publiczną jak podatki, to jednak należy zaliczyć je do tej samej grupy ciężarów i świadczeń publicznych stanowiących źródła dochodów państwa. Skoro tak, to nałożenie obowiązku świadczeń tego rodzaju oznacza ingerencję w prawo dysponowania środkami pieniężnymi należącymi do majątku osoby obciążonej tym obowiązkiem. Dlatego przepisy regulujące problematykę danin publicznych i ich stosowanie muszą być zgodne $\mathrm{z}$ całokształtem obowiązujących norm i zasad konstytucyjnych. Stosowanie przepisów zobowiązujących do uiszczania opłat za usługi wodne nie może prowadzić do naruszenia wartości objętych ochroną konstytucyjną, a w szczególności nie może prowadzić do tego, ażeby opłaty te stały się instrumentem nadmiernego fiskalizmu. Władczość państwa jako źródło obowiązku opłat za usługi wodne oraz minimalny lub żaden wpływ jednostki na treść tego stosunku prawnego wymagają ścisłego, zgodnego z zakładanym celem ustawy, stosowania przepisów określających ten obowiązek" ${ }^{33}$.

Przyjmując powyższą argumentację dotyczącą opłat za usługi wodne jako mającą również zastosowanie do ustalania opłaty rocznej z tytułu prawa do dysponowania

28 Wyrok TK z dnia 25 kwietnia 2001 r., K 13/01, OTK ZU 2001, z. 4, poz. 81.

29 Wyrok TK z dnia 11 kwietnia 2000 r., K 15/98, OTK ZU 2000, z. 3, poz. 86.

30 Tak np.: wyrok TK z dnia 9 listopada 1999 r., K 28/98, OTK ZU 1999, z. 7, poz. 156. Zob. także wyrok TK z dnia 16 marca 2010 r., K 24/08, Dz. U. z 2010 r. Nr 48, poz. 285.

31 Wyrok TK z dnia 16 marca 2010 r., K 24/08, OTK ZU 2010, z. 3A, poz. 22; K. Działocha, A. Łukaszczuk, w: Konstytucja Rzeczypospolitej Polskiej. Komentarz, red. L. Garlicki i in., t. 2, wyd. 2, 2016 [wyd. el. LEX], Komentarz do art. 84 Konstytucji, teza 3.

32 Wyrok TK z dnia 21 czerwca 2004 r., SK 22/03, OTK ZU 2004, z. 6A, poz. 59.

33 Wyrok WSA w Gdańsku z dnia 1 sierpnia 2018 r., II SA/Gd 297/18, LEX nr 2528477. 
częstotliwością, wskazać należy, że w przypadku opłaty za prawo do dysponowania częstotliwością wykładnia przepisu art. 185 ust. 1 ustawy Prawo telekomunikacyjne musi być zgodna z całokształtem obowiązujących norm i zasad konstytucyjnych. Stosowanie przepisów zobowiązujących do uiszczania opłat za prawo do dysponowania częstotliwością nie może prowadzić do naruszenia wartości objętych ochroną konstytucyjną, a w szczególności nie może prowadzić do tego, by opłaty te stały się instrumentem nadmiernego fiskalizmu. Chodzi o gwarancje konstytucyjnej ochrony wolności praw jednostki i innych podmiotów obrotu gospodarczego, wyrażone w art. 2, art. 20 oraz art. 31 ust. 3 Konstytucji RP.

W konsekwencji wymagalność uiszczenia rocznej opłaty z tytułu prawa do dysponowania częstotliwością ma miejsce tylko wtedy, gdy poprzez wydanie decyzji w sprawie rezerwacji częstotliwości podmiot uzyskał możliwość zrealizowania wszelkich praw związanych z prawem dysponowania częstotliwościami. Jak zostało wskazane powyżej, „prawo do dysponowania częstotliwością w rezerwacji częstotliwości” rozumieć należy jako prawo do żądania wydania pozwolenia radiowego lub pozwoleń radiowych na podstawie wniosku strony, bez zbędnej zwłoki, zgodnie $\mathrm{z}$ art. 12 K.p.a. w zw. z art. 206 ust. 1 ustawy Prawo telekomunikacyjne oraz w terminach wskazanych w art. 143 ust. 6 albo 7 tej ustawy. Celem, dla którego z prawa tego strona zamierza skorzystać, jest wykorzystanie częstotliwości w działalności telekomunikacyjnej.

\section{Naruszenie art. 185 ust. 1 ustawy Prawo telekomunikacyjne przez sąd pierwszej instancji}

Z analizy stanu faktycznego, na tle którego zapadł glosowany wyrok, wynika zatem, że Prezes UKE zażądał od S. S.A. zapłaty za:

1) odebranie S. S.A. częstotliwości na podstawie decyzji z grudnia 2013 r.;

2) rezerwację częstotliwości $z$ Nowego Pasma bez prawa do dysponowania tymi częstotliwościami przez okres jednego roku, tj. od 31 grudnia 2013 r. $^{34}$ do 31 grudnia $2014 \mathrm{r}$.

Ani w ustawie Prawo telekomunikacyjne, ani też w żadnym innym przepisie obowiązującego prawa nie przewidziano zapłaty na rzecz Skarbu Państwa za wystąpienie powyższych zdarzeń wskazanych w punktach 1-2, spowodowanych

34 Data doręczenia S. S.A. decyzji z grudnia 2013 r., której nadany został rygor natychmiastowej wykonalności. 
zamierzonym działaniem Prezesa UKE wobec S. S.A. W związku z powyższym uiszczona przez S. S.A. płatność powinna być kwalifikowana jako nadpłata w rozumieniu art. $72 \S 1$ pkt 1 ustawy z dnia 29 sierpnia $1997 \mathrm{r}$. - Ordynacja podatkowa ${ }^{35}$ w zw. z art. 188 ustawy Prawo telekomunikacyjne. Prezes UKE wydał decyzję oraz poprzedzającą ją decyzję pierwszej instancji z naruszeniem prawa.

Istota nadpłaty sprowadza się bowiem do tego, że podatnik płaci wówczas, gdy nie musi tego robić (nie istnieje obowiązek podatkowy), albo płaci za dużo (kwota podatku zapłaconego przewyższa kwotę należną) $)^{36}$. Kluczowe dla rozstrzygnięcia sądu pierwszej instancji było stwierdzenie zawarte w uzasadnieniu wyroku z 2016 r.: „[...] pobieranie opłat jest związane z prawem do dysponowania częstotliwością, a nie z używaniem częstotliwości”. Sąd pierwszej instancji nie przeprowadził kompletnej wykładni językowej (gramatycznej) tego przepisu, opartej na egzegezie hipotezy i dyspozycji przepisu. Ponadto sąd pierwszej instancji pominął wykładnię celowościową oraz systemową.

Sąd pierwszej instancji pomylił termin „prawo do dysponowania częstotliwością w rezerwacji częstotliwości”, wskazany w art. 185 ust. 1 ustawy Prawo telekomunikacyjne, z terminem „prawo do dysponowania rezerwacją częstotliwości”, wskazanym w art. 122 ust. 1 oraz art. $122^{1}$ ust. 1 ustawy Prawo telekomunikacyjne. Podstawowe znaczenie słowa dysponować to „mieć coś do dyspozycji” ”, „mieć możliwość użycia czegoś”38. Jak zostało wskazane w pkt 3 , „dysponowanie częstotliwością” polega na żądaniu wydania pozwoleń radiowych. Bez możliwości pozyskiwania pozwoleń radiowych uprawnienie z rezerwacji jest uprawnieniem „iluzorycznym”, zaś podmiot wskazany w decyzji „nie ma rezerwacji do dyspozycji”.

Istota rezerwacji częstotliwości polega na tym, że podmiot uprawniony uzyskuje w tym zakresie wyłączność. Żaden inny podmiot nie może bowiem daną częstotliwością „dysponować na cele pozyskiwania pozwoleń radiowych”. W sytuacji, w której podmiot wskazany w decyzji rezerwacyjnej nie może uzyskać pozwoleń radiowych, $\mathrm{z}$ decyzji rezerwacyjnej nie wynika ani uprawnienie, ani wyłączność. Natomiast dopiero na podstawie uzyskanych pozwoleń radiowych podmiot uprawniony może z rezerwacji częstotliwości „korzystać” (a nie „używać”, jak błędnie wskazał sąd pierwszej instancji w wyroku z 2016 r.). W odróżnieniu od „prawa do dysponowania częstotliwością” termin „prawo do dysponowania rezerwacją

35 Tekst jednolity: Dz. U. z 2019 r. poz. 900 z późn. zm.

36 Zob. wyrok WSA w Gliwicach z dnia 14 maja 2018 r., I SA/GI 1219/17, LEX nr 2502372; wyrok WSA w Lublinie z dnia 20 kwietnia 2018 r., I SA/Lu 1009/17, LEX nr 2499632; wyrok NSA z dnia 4 czerwca 2014 r., I FSK 907/13, LEX nr 1487675.

37 Słownik języka polskiego, https://sjp.pwn.pl/sjp/dysponowac;2555797.html [dostęp: 19.04.2020 r.].

38 https://pl.wiktionary.org/wiki/dysponowa\%C4\%87 [dostęp: 19.04 .2020 r.]. 
częstotliwości” odnosi się do prawa do żądania od Prezesa UKE udzielenia zgody na zmianę podmiotu, który dysponuje rezerwacją częstotliwości, wydzierżawienia częstotliwości objętych rezerwacją lub przekazania do użytkowania na podstawie innego tytułu prawnego na rzecz innego podmiotu.

Sąd pierwszej instancji w wyroku z 2016 r. nie dostrzegł, że ustawodawca zastosował w ustawie Prawo telekomunikacyjne rozróżnienie na „dysponowanie częstotliwością” lub „Zasobem” (np. art. 114 ust. 1, art. 118 ust. 4a, art. 119 ust. 2 ustawy Prawo telekomunikacyjne) oraz „dysponowanie rezerwacją częstotliwości” (art. 122 ust. 1, art. $122^{1}$ ust. 1 ustawy Prawo telekomunikacyjne). Dokonana przez sąd pierwszej instancji wykładnia przepisu art. 185 ust. 1 ustawy Prawo telekomunikacyjne nie uwzględniała, że - jak podkreśla się w literaturze przedmiotu - swoboda ustawodawcy w zakresie kształtowania regulacji podatkowych jest ograniczona koniecznością poszanowania wartości i zasad konstytucyjnych, w tym zwłaszcza wynikających z art. 2 Konstytucji RP, takich jak zasada proporcjonalności, zasada sprawiedliwości podatkowej oraz zasada prawidłowej legisla$\mathrm{cji}^{39}$. W literaturze przedmiotu zasada sprawiedliwości podatkowej traktowana jest jako wyrażająca się $\mathrm{w}$ równości podatkowej ${ }^{40} \mathrm{i}$ wiąże się tę zasadę z postulatem ekwiwalentności ${ }^{41}$.

Obciążenie podatkiem - świadczeniem przymusowym, z którego środki służą całemu rynkowi telekomunikacyjnemu (konkurentom S. S.A.), stanowi realizację zasady sprawiedliwości prawa oraz sprawiedliwości podatkowej. Następuje bowiem wzbogacenie danego podmiotu (tu w teorii S. S.A.) poprzez przyznanie na jej rzecz jakiegoś dobra wspólnego kosztem innych członków wspólnoty. Odebranie S. S.A. prawa do „dysponowania częstotliwością na cele związane z uzyskiwaniem pozwoleń radiowych” w danym roku kalendarzowym (2014), choć przed zmianą rezerwacji częstotliwości podmiot ten takie prawo posiadał, nie stanowi poszerzenia jego uprawnień, ale ich zawężenie. Beneficjentem ekonomicznym takiego rozwiązania nie jest S. S.A., lecz jego konkurenci rynkowi.

39 M. Florczak-Wątor, w: Konstytucja Rzeczypospolitej Polskiej. Komentarz, red. P. Tuleja, 2019 [wyd. el. LEX].

40 R. Lipniewicz, Jurysdykcja podatkowa w cyberprzestrzeni, 2018 [wyd. el. LEX].

41 A. Gomułowicz, Zasada sprawiedliwości podatkowej, Warszawa 2001, s. 28. 


\section{Zakończenie}

Wyrok NSA z dnia 27 listopada 2018 r. zawiera istotne rozstrzygnięcie w przedmiocie określenia znaczenia terminu „prawo do dysponowania częstotliwością" w kontekście określenia podstawy prawnej obowiązku uiszczenia rocznych opłat, o których mowa w art. 185 ust. 1 ustawy Prawo telekomunikacyjne. Analiza podstaw materialnoprawnych obowiązku uiszczenia rocznych opłat za prawo do dysponowania częstotliwością, w tym dokonana wykładnia terminu „prawo do dysponowania częstotliwością", doprowadziła NSA do następującego wniosku, zawartego w tezie nr 1. Nie można uzyskania „prawa do dysponowania częstotliwością” jako podstawy do nałożenia opłaty, o której mowa w art. 185 ust. 1 ustawy Praw telekomunikacyjne, wywodzić jedynie $\mathrm{z}$ faktu wydania decyzji w sprawie rezerwacji częstotliwości, wskazanej w art. 114 ust. 1 tej ustawy, zaopatrzonej w rygor natychmiastowej wykonalności bądź decyzji ostatecznej albo - w przypadku wniesienia skargi na decyzję ostateczną - decyzji prawomocnej. Na podstawie wydanej decyzji w sprawie rezerwacji częstotliwości musi dodatkowo istnieć realna możliwość podmiotu uprawnionego z tej decyzji do występowania do Prezesa UKE o wydanie pozwolenia radiowego $\mathrm{w}$ celu wykorzystania częstotliwości w ramach prowadzonej działalności telekomunikacyjnej ${ }^{42}$. Aprobując stanowisko sądu, zawarte w pierwszej tezie, podkreślić należy, że decyzja w sprawie rezerwacji częstotliwości nie uprawnia podmiotu wskazanego w tej decyzji do wykorzystania zarezerwowanych częstotliwości do celów działalności telekomunikacyjnej. Wykorzystanie częstotliwości do celów prowadzonej działalności telekomunikacyjnej odbywa się za pomocą urządzeń radiowych. W tym przypadku ustawodawca wprowadził do ustawy Prawo telekomunikacyjne drugi poziom reglamentacji działalności telekomunikacyjnej z wykorzystaniem częstotliwości poprzez wymóg uzyskania pozwolenia radiowego ${ }^{43}$. Choć postępowania $\mathrm{w}$ sprawie wydania decyzji rezerwacyjnej oraz pozwolenia radiowego są postępowaniami odrębnymi, wszczynanymi co do zasady na wniosek, to jednak istnieje pomiędzy nimi więź funkcjonalna. Przy uwzględnieniu znaczenia częstotliwości jako dóbr rzadkich łącznikiem pomiędzy tymi postępowaniami jest wymóg efektywnego wykorzystywania częstotliwości. Niewykorzystywanie w działalności telekomunikacyjnej poprzez używanie urządzeń radiowych przydzielonej częstotliwości powoduje, że Prezes UKE może decyzję rezerwacyjną zmienić lub cofnąć, działając $\mathrm{z}$ urzędu na podstawie art. 123 ust. 1 pkt 8 ustawy

42 Na temat definicji legalnej terminu „działalność telekomunikacyjna” zob. art. 1 ust. 1 pkt 1 Prawa telekomunikacyjnego.

43 A. Krasuski, Prawo telekomunikacyjne Komentarz, Warszawa 2015, s. 954. 
Prawo telekomunikacyjne. Z dniem doręczenia S. S.A. decyzji z grudnia 2013 r., opatrzonej rygorem natychmiastowej wykonalności, operatorowi ${ }^{44}$ temu odebrane zostały częstotliwości i przyznane zostały nowe częstotliwości z pasma $800 \mathrm{MHz}$, przy czym na podstawie decyzji z grudnia 2013 r., a następnie decyzji z września 2014 r. - które wydane zostały przez Prezesa UKE z urzędu - S. S.A. pozbawiona została prawa ubiegania się o wydanie pozwoleń radiowych do dnia 31 grudnia 2014 r. Tym samym Organ pozbawił S. S.A. prawa do dysponowania częstotliwościami z Nowego Pasma przez okres jednego roku. Przy uwzględnieniu wskazanej wyżej argumentacji należy ocenić drugą z tez zawartych w glosowanym wyroku. Co prawda w tezie tej NSA wskazuje wprost na pozbawienie S. S.A. „prawa do korzystania z częstotliwości”, to jednak uwzględniając rozdział zasad reglamentacji działalności telekomunikacyjnej z wykorzystaniem częstotliwości na decyzje w sprawie rezerwacji częstotliwości i pozwolenia radiowe, zamiarem NSA było uwypuklenie przedstawionego wyżej związku funkcjonalnego pomiędzy tymi postępowaniami. Sąd w tezie tej wskazuje bowiem na wynikające z decyzji w sprawie rezerwacji częstotliwości prawo do wystąpienia z wnioskiem do Organu o wydanie pozwolenia radiowego. Podzielając stanowisko NSA o naruszeniu art. 13 Dyrektywy, należy zaaprobować również drugą z tez.

\section{Bibliografia}

Adamiak B., Borkowski J., Kodeks postępowania administracyjnego. Komentarz, Warszawa 2011.

Brzeziński B., Szkice z wykładni prawa podatkowego, Gdańsk 2002.

Działocha K., Łukaszczuk A., w: Konstytucja Rzeczypospolitej Polskiej. Komentarz, red. L. Garlicki i in., t. 2, wyd. 2, 2016 [wyd. el. LEX].

Florczak-Wątor M., w: Konstytucja Rzeczypospolitej Polskiej. Komentarz, red. P. Tuleja, 2019 [wyd. el. LEX].

Gomułowicz A., Zasada sprawiedliwości podatkowej, Warszawa 2001.

Jakimowicz W., Wykładnia w prawie administracyjnym, Zakamycze 2006.

Kosikowski C., Legislacja finansowa, Warszawa 1998.

Krasuski A., Prawo telekomunikacyjne Komentarz, Warszawa 2015.

Lipniewicz R., Jurysdykcja podatkowa w cyberprzestrzeni, 2018 [wyd. el. LEX].

Nałęcz A., w: Kryzys prawa administracyjnego?, t. 1. Jakość prawa administracyjnego, red. D.R. Kijowski, A. Miruć, P.J. Suwaj, 2012 [wyd. el. LEX].

Przybysz P., Kodeks postępowania administracyjnego. Komentarz, 2019 [wyd. el. LEX].

44 Na temat definicji legalnej terminu „operator” zob. art. 2 pkt 27 lit. b ustawy Prawo telekomunikacyjne. 
Andrzej Krasuski

Słownik języka polskiego, t. 1, red. S. Dubisz, Warszawa 2003.

Starościak J., Prawo administracyjne, Warszawa 1977.

Wincenciak M., Sankcje w prawie administracyjnym i procedura ich wymierzania, Warszawa 2008.

Zieliński M., Wykładnia prawa. Zasady. Reguły. Wskazówki, Warszawa 2002. 